Vladan Petrović ${ }^{1}$

Marija Lakićević ${ }^{2}$

University of Kragujevac, Serbia

Faculty of Hotel Management and Tourism

\section{Milica Žarevac Bošković}

Technical College of Applied in Kragujevac
ORIGINAL SCIENTIFIC ARTICLE

DOI: 10.5937/ekonomika2004062P

Received: March, 17. 2020.

Accepted: October, 02. 2020.

\title{
CULTURAL AND RELIGIOUS TOURISM IN KOSOVO AND METOHIJA
}

\begin{abstract}
The culture and cultural heritage are an expression of a nation's identity, history, tradition and civilization, an indicator of its life in time and space. This paper focuses on the analysis of cultural and religious tourism in Kosovo and Metohija area. The primary data was collected through a survey method, in August 2018, by a sample group of 38 respondents who participated in an organized two-day trip. The goal of this paper is to present the current state of cultural heritage and the significance which religious and cultural tourism have for the development of the local community on Kosovo and Metohija. Results of the research indicate that cultural and religious tourism contributes to regional development, cultural values, but also that a large number of monasteries and churches located in this area represent true sanctity for our people.

The purpose of this paper is to point out the importance of cultural and religious tourism on the development of local communities in Kosovo and Metohija, but also to point out the fact that sacral buildings in this area have great, sacred value for our people. The research was conducted through a multidimensional questionnaire. The obtained data were processed manually by the authors of this paper, since the research sample is restrictively small. The scientific research methods used in the paper are the methods of analysis and synthesis, the method of induction and deduction, as well as the method of descriptive analysis.

On that occasion, we found that cultural and religious tourism is very developed in this area, despite the unrest that has marked the last decade. Also, it was determined that these forms of tourism are of great importance for the community in Kosovo and Metohija. Tourists view the sacral buildings in this area as great shrines to which they show great respect. The practical implications of this paper are reflected in the fact that the obtained results can be used in further research.
\end{abstract}

Key words: cultural tourism, religious tourism, development, local community, Kosovo and Metohija.

JEL classification: Z12, Z32

\footnotetext{
${ }^{1}$ vladanpetrovicvb@outlook.com, ORCID ID 0000-0001-9642-1106

2 marija.lakicevic@kg.ac.rs, ORCID ID 0000-0003-2169-7575

${ }^{3}$ zarevac.milica@gmail.com, ORCID ID 0000-0003-3839-3340
} 


\title{
КУЛТУРНИ И ВЕРСКИ ТУРИЗАМ КОСОВА И МЕТОХИЈЕ
}

\begin{abstract}
Апстракт
Кулитура са кулишурном башитином је израз иденииитейа народа, юегове

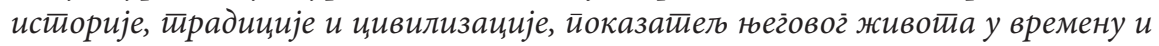
иростиору. У фокусу овог̄ рада налази се анализа куличурног̄ и верског̄ тиуризма на йодручју Косова и Метиогије. Примарни йодаци ирикуйлени су мейодом анкейирана, у авгіустиу 2018. године, на узорку од 38 исиитианика који су били учесници организованог дводневног йуйована. Цит рада јесте да ирикаже значај који верски и кулитурни тиуризам има за развој локалне заједнице на Косову и Метоохији. Резулитаии истираживана указују да кулитурни и верски ииуризам доириносе регіионалном развоју, куличурним вредностимма, али и да велики број манастиира и иркава који се налазе на овом йодручју, иредсииавља за наш народ ирраву светиости.

Сврха овог̈ рада је да укаже на значај кулитурног̈ и верског̈ йуризма на развој локалних заједница на Косову и Метохији, али и на чиненииу

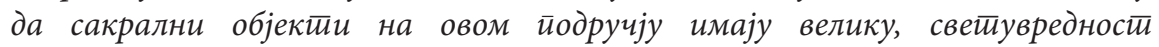
за наш народ. Истираживане је сироведено кроз више димензионални уииитник. Добијене йодайке ауйори овог рада обрађују ручно, јер је узорак истираживана ресирикиивно мали. Мейоде научног истираживана које се користе у раду суметиоде анализе и синиеезе, метиода индукиије и дедукиије, као и метиода ойисне анализе. Том ирриликом смо уйврдили да је кулитурни и верски ииуризам веома развијен на овом йодручју,уиркос немирима који су обележили иоследюу деценију. Такође, уйврђено је да су ови облиии ичуризма од великог значаја за заједнииу на Косову и Метиохији. Туристии сакралне грађевине на овом йодручју виде као велика светиилишита ирема којима йоказују велико иомитоване. Пракииччне имйликације овог рада ог̆ледају се у чиюеници да се добијени резулитати могу користиити у даљим истраживањима.
\end{abstract}

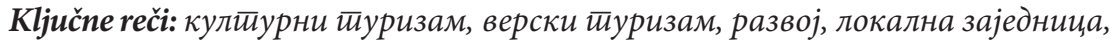
Косово и Метиохија.

\section{Introduction}

The question of future development of tourism is asked all over the world for a good reason (Šušić \& Đorđević, 2019). The newest trends in this industry indicate on increased demand for new alternative forms of tourism (Sagić, et al., 2019). Also, changes in needs and demands of tourists have in recent years led to significant changes in the tourism market. Tourists are more demanding, educated and sophisticated, which leads to a need for new tourist products in tourism offers. A need for new events in some new destinations appears. All these changes lead to a situation in which specific forms of tourism gain in significance, and especially cultural tourism among them.

Cultural tourism denotes movement of people which is caused by culturalattractions beyond their usual place of residence, with the intention of collecting new information and experiences in order to satisfy their cultural needs (Richards, 
2005, p.16). For that reason, cultural tourism belongs to areas which border cultural geography and studies which analyze cultural mobility, cultural identity and relations between societies on different levels of development (Petroman, 2013). The definition of cultural tourism includes historical, artistic, ethnical, religious, sport and other forms of selective tourism (Sančanin, et al., 2019). Cultural tourism emphasizes richness in material and non-material heritage of a specific area in order to realize numerous positive economic, ecological and social effects. On one hand, cultural tourism enables development and improvement of a destination, and on the other hand, it increases public awareness of special cultural and historical values and their preservation. Cultural heritage is an authentic and unrepeatable resource (Sančanin et al., 2019).

Religious tourism can be defined as a visit to specific tourist spots where visitors have a chance to experience religious events and locales. Religious tourism is also called pilgrimage tourism. As such, it implies a type of tourism where people travel individually or in groups on pilgrimages, for missionary or free (common) purposes (Chianeh, et al., 2018).

Religion and faith have always been strong motivators in evolution of society and movements of people. Among other things, religion and pilgrimage also have significant economic implications in contemporary societies. Religious tourism plays an important role in development of local economy and for many destinations it is a new form of tourist activity. Religious tourism is an additional source of income for many rural economies (Kilipiris \& Dermetzopoulos, 2016). Pilgrims, as well as religious tourists, travel on religious tours when they feel the need to do more than regular cult activities in conditions of a regular environment of their place of residence. Thereby, the peoples' motives for visits to holy places are different: for prayer, solving personal problems, finding a suitable religion, theological education or system of values, or for familiarization with a country's cultural heritage (Yakunin\&et.al., 2016).

The subject of this paper is gaining an insight into influences of cultural and religious tourism on tourism development of the local community in Kosovo and Metohija. A large number of monasteries, churches and church areas on Kosovo and Metohija are places of historical roots and future. The institution which has integrated Serbian people through centuries, and which to this day has the most important spiritual and moral power is the Serbian Orthodox Church. It preserves the national and religious identity and it is the institution which has preserved through centuries the concept of sobornost on Kosovo and Metohija (Avramović, 2018). Cultural tourism may be realized by the benefit for the local populace, through many complementary service and other activities in the form of economic convenience, enabling development for social minorities, reviving tradition, harmonization, etc. (Damnjanović, et al., 2016). A number of churches and monasteries which were destroyed or damaged during the war on Kosovo and Metohija were rebuilt, and devotional trips to them are organized. A visit to these monasteries represents sanctity for the people and nation of Serbia. For monasticism, but also for other Serbs in these areas, devotional travels represent a form of support and a message that they are not forgotten (Anđelković, 2019). The development of religious and cultural tourism which would include preservation of customs for monasteries and realization of financial effects could significantly increase through tourism cooperation of Serbia and Serbian Orthodox Church (Živadinović \& Knežević, 2018). 
The aim of this paper is to present certain aspects of the importance of religious and cultural tourism for the development of the local community in Kosovo and Metohija.

\section{Matherial and metod of work}

As a research instrument, a multidimensional survey questionnaire with a general and special part was used, which contained 8 questions. The general part examined the socio-demographic structure of the respondents, while the special part contained 8 questions whose answers were formed according to the principle of rounding and supplementation. The questionnaire was originally designed by the author of this paper. The obtained data were processed manually by the authors of this paper, without the use of statistical programs, since the research sample is small. In the research, we started from the general hypothesis X0: Religious and cultural tourism is of great importance for the development of the local community in Kosovo and Metohija. On that occasion, a special hypothesis was identified, which reads, X1: A large number of monasteries and churches located in this area, represents true holiness for our people.

The methods used in the study of professional literature dealing with the topic as well as this paper are: methods of analysis and synthesis and methods of induction and deduction.

\section{Literature review}

Culture is an integral part of the entire social and individual life. It represents a collection of the entire human heritage, material (material culture) as well as spiritual (spiritual culture), without which the existence of human society could not even be imagined, not even in the simplest forms of its organization (ĐukićDojčinović 2005, p. 15). World Tourist Organization has provided two definitions for the concept of cultural tourism: in a narrow sense, cultural tourism means "the movement of people with strong cultural motivation - fine arts, travels to festivals and other cultural events, visits to landmarks and monuments"; and in a broad sense it means "all movements of people for satisfying human needs for diversity, directed at increasing the individual's cultural level and gaining new knowledge and experiences" (World Tourist Organization (UNWTO): www2.unwto.org).

The basic functions of cultural tourism are to represent the national and local values to a tourist, as well as to enrich tourist destinations with cultural content, and to make them more attractive for the domestic population. That means that, thanks to cultural tourism, festivals, cultural and art manifestations, local celebrations and artistic programs attract the tourist, as well as the local populace. In other words, culture always attracts tourists, and the only question is whether it is visible or hidden for them. For that reason, the main problem of cultural tourism lies in activation, preservation and presentation of cultural possibilities (Đukić Dojčinović, 2005).

The idea of religious pilgrimage has developed in very early stages of human history, which is why religious tourism is one of the earliest forms of tourism (Kilipiris\& Dermetzopoulos, 2016). Religious tourism implies tourist trips with the purpose of 
satisfying religious needs by visiting religious centers, holy places, monuments, buildings, locales, religious festivals, etc. Religion is very closely connected with tourism, and it represents a very strong motive for travel (Chianeh, et al., 2018). When we talk about religious tourism we think of pilgrimages, but also of travels and visits to religious locales with the basic motive of connection, study and familiarization of religious traditions and heritage (Skoultsos \& Vagionis, 2015). When it comes to religious tourism, the motivation which a tourist can feel cannot be initiated only by cognitive, educational and cultural needs, but by spiritual ones as well (Nedeljković, 2018).

It should also be noted that religious tourism contributes to regional development, as well as that pilgrimage tourism may restore cultural values (Pourtaheri, et al., 2012). Religious tourism, as a branch of tourism, attracts more and more attention of world tourism organizations, as well as of many authors in the sense of a branch which may have an important influence on increasing the social product and national income. While certain authors consider that religious tourism may cause an increase in the social product and in the growth of the national income, others, as far as Serbia is concerned, present a thesis that religious tourism cannot impact significantly the growth of the national income, or it cannot reduce the number of unemployed people, and that also it may have an adverse effect on spirituality and the Serbian Orthodox Church (Mićunović, 2015 , p. 44). Religious tourism is not related only on the form of tourism with a strong and unanimous motive for pilgrimage, but also to tourist activities which are not related to pilgrimage, such as travels for viewing religious landmarks, cultivation and recreation (Heidari, et al., 2017). It can be said that religious tourism benefits all of its participants. First, religious entities can expect an income from donations and charity organizations. Second, religious tourists can leave charity contributions and buy souvenirs, so the income can be invested into restoration of certain local craftsman activities (Durán-Sánchez, et al., 2018). When compared to a pilgrim, a religious tourist is primarily motivated by cultural knowledge, while a pilgrim is primarily motivated by religion. The number of tourists who visit religious places has increased multiple times, despite the growing number of atheists and agnostics and the declining significance of religion in the Western world (Bogan, et al., 2019). There is a traditional belief that a man who is religious by nature often leaves his home near the end of his life cycle in order to visit sacred places, so as to separate from his worldly life. Travels whose purpose is pilgrimage represent a basis which leads to the development of a phenomenon called tourism (Sivakumar, et al., 2019). Religious tourism encourages us to learn tradition and customs of different ethnic groups and cultures, promotes spirituality and patriotic education of the populace, and thus offers a chance for gathering of people while striving for world peace (Eidelman, et al., 2017).

\section{Research Design}

The method used for collection of relevant data is the survey method. For the purposes of this paper we have conducted a survey about opinions of bus passengers organized by Balkan Turs - KIMKO agency from Niš. In other words, the primary data was collected with a method of surveying all participants of this two-day trip, who answered ten close-ended questions. 38 complete surveys were collected. While constructing 
the survey we took into consideration its length, meaningfulness of questions, and their relevance to the given topic. The survey was available to everyone who wanted to participate in it, regardless of gender, age, employment status, ethnical background, etc. The survey was anonimous, so the respondents' names cannot be publicized.

Namely, the plan for the first day included visits to the Patriarchate of Peć, monastery Dečani, monastery of the Holy Archangels, city of Prizren, the church of Our Lady of Ljeviš, the church of St. George in the center of Prizren and Orthodox Seminary of Prizren. In the evening there was a concert of the famous opera singer Divna Ljubojević, which was organized within the international medieval music festival Medimus. The plan for the second day included visits to the monastery Zočište and attendance of the Holy Liturgy, afterwards returning to Velika Hoča and a tour of that Serbian enclave. Also, the program included the visit to the monastery Gračanica. The organizer of the trip agreed, at the passengers' wish and coaxing, to visit and have a tour of Gazimestan, a significant historical monument for Serbia. On this occasion, the visitors were warned about movement restrictions, behaviour and opportunities to spend money. Namely, individual movement was free inside monastery walls, in Velika Hoča and Gračanica, while group movement was free in Prizren. Monastery shops were notified about the visit in advance. A possibility of visits and donations to Serbian families who need material help, and who live in enclaves was also announced in advance on this occasion.

\section{Research results and Discussion}

It is estimated that around 89100 inhabitants of Serbian nationality live in enclaves in Kosovo and Metohija. The largest number of Serbian populace lives on the territory of Central Kosovo - around 40000 or $44.9 \%$ of the populace of Serbian enclaves. The largest number of Serbs after Central Kosovo lives in enclaves of Kosovsko Pomoravlje, 35000 or $39.3 \%$ of the populace. 12000 Serbs or $13.5 \%$ of the total enclave dwelling populace lives in mountain villages of Šar Mountains, located in the south of Kosovo. The smallest number of Serbs, 2100 or 2.3\% of the enclave population lives in Metohija enclaves (Milosavljević, 2013).

UNMIK is responsible for preservation of cultural heritage, considering that the location of Kosovo and Metohija is under protectorate, based on resolution 1244 of UN Security Council. 155 of 1300 of orthodox churches and monasteries and 24 cultural monuments in Kosovo and Metohija were damaged or destroyed. State authorities of Serbia estimate that more than 10000 icons, ecclesiastical artworks and worship objects, and old manuscripts were stolen or destroyed after the arrival of UNMIK and KFOR (Mihajlović \& Mihajlović, 2013). A problem of lack of data on the Kosovo and Metohija territory is stated in Tourism Development Strategy of the Republic of Serbia for the period from 2016 to 2025(Katanić, 2017). Because of problems with the status of Kosovo and Metohija,it is pointless at this point to compare the status of the southern province with the restparts of the Republic of Serbia(Molnar \& Manić, 2018).

Significant wealth in the form of cultural and historical monuments is located in this area. Consumption of cultural heritage, a sensitive resource, rises faster than creation and realization of tourism plans and protection (Radović, et al., 2018).

The most significant medieval temples of the Serbian Orthodox Church are located in Kosovo and Metohija, the most famous of them being: XIV century monastery Visoki 
Dečani, XIV century monastery Gračanica, XIV century church of Our Lady of Ljeviš, XIIIXIV century monastery Patriarchy of Peć, XIV century monastery of the Holy Archangels, XV century monastery Devič, XIII century monasteries and churches in Velika Hoča, XIV century monastery Sokolica, and XIV century monastery Banjska. Monasteries on the UNESCO World Heritage list are: the monastery Visoki Dečani, Patriarchy of Peć, the church of Our Lady of Ljeviš in Prizren, and the monastery Gračanica (Katanić, 2017).

The goal of cultural tourism development and preservation of cultural diversity is to find a way to realize equal legal and physical protection of cultural heritage of the Serbian community, which is currently under the authority of the political decision maker on Kosovo and Metohija territory. The basic premise of cultural tourism development consists of cultural diversity and rich cultural and historical heritage of people who live and have lived on the Kosovo and Metohija territory (Radović, et al., 2018).

All respondents were participants in an organized two-day trip through Kosovo and Metohija from August 2018. The majority of the respondents were female - $60.5 \%$ (23 respondents), while male respondents consisted 39.5\% of the group (15 respondents). Agewise, the largest number of 12 respondents were persons older than 60, 11 respondents were $35-59,10$ respondents were $19-24$, while the remaining 5 respondents were younger than 18. As for the employment status, the majority, i.e. 17 persons, were employed, 9 persons were retired, 8 persons were students, two were unemployed, and two were entrepreneurs. Regarding education, 19 persons had college education, 12 had high school education, 4 had a Master's degree, and three had only elementary school education. The survey consisted of 10 questions related to contents of the trip to Kosovo and Metohija.

When asked "Are you visiting Kosovo and Metohija for the first time since 1999?" 19 respondents answered that they were visiting Kosovo and Metohija for the first time, 12 respondents answered that since 1999 they have visited Kosovo and Metohija once, while 7 respondents answered that they visit that region often.

The following chart will show the respondents' answers to the question: "What is the reason for your visit to Kosovo and Metohija this time?"

Picture 1: The structure of answers for the question "What is the reason for your visit to Kosovo and Metohija this time?"

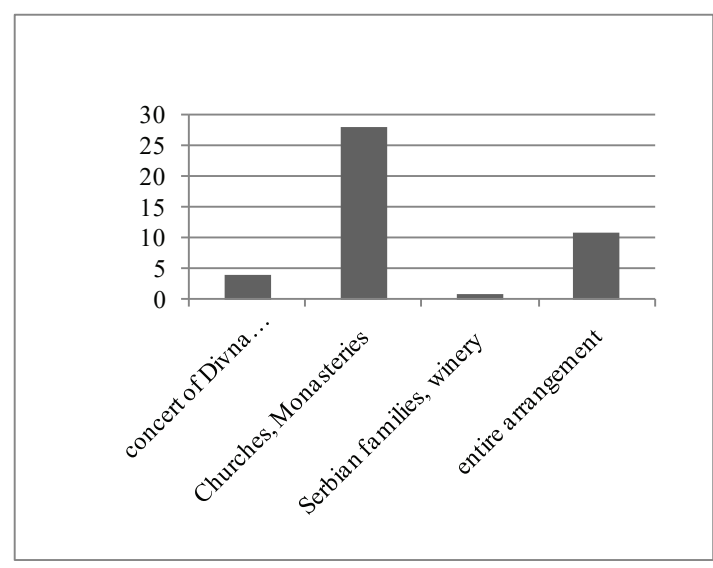

Source: Authors 
Based on these answers, we can observe that visits to Churches and Monasteries were the main reason for the trip to Kosovo and Metohija for the majority, while the entire tourism arrangement was the reason for somewhat fewer people, meaning that we can say that the religious tourism is absolutely dominant. The concert and Medimus festival, which by their nature represent cultural tourism, are the reason for a small number of respondents. Taking the abovementioned into consideration, we can conclude that this trip is primarily classified as religious and cultural tourism.

When asked "How did you find out about this trip?" the total of 20 respondents answered that they found out about the trip from a friend's or a relative's recommendation. 9 respondents found out from posters, flyers, and agency advertisements, while 5 respondents found out via social networks, and 4 answered that they have found out in some other way. The total of three respondents stated that they received information from the Church.

The following chart will show the structure of respondents' answers to the question: "Have you bought anything during yourstay in Kosovo and Metohija?"

Picture 2: The structure of answers to the question "Have you bought anything during your stay in Kosovo and Metohija?"

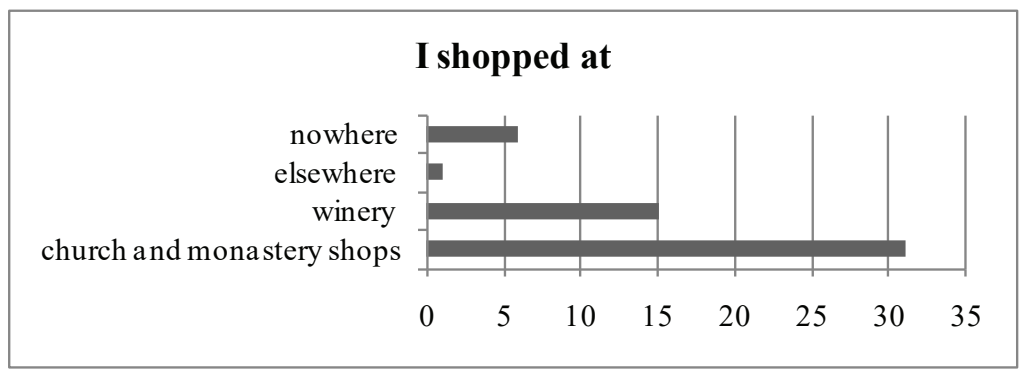

Source: Authors

Based on these answers we can observe that the absolute majority of respondents shopped at stores to which the visits were announced in the tourism arrangement, and in that way confirmed the economic contribution to the local community on Kosovo and Metohija.

The structure of answers to the question "Did you make a donation during your stay in Kosovo and Metohija?" is represented in picture 3.

Picture 3: The structure of answers to the question "Did you make a donation during your stay in Kosovo and Metohija?"

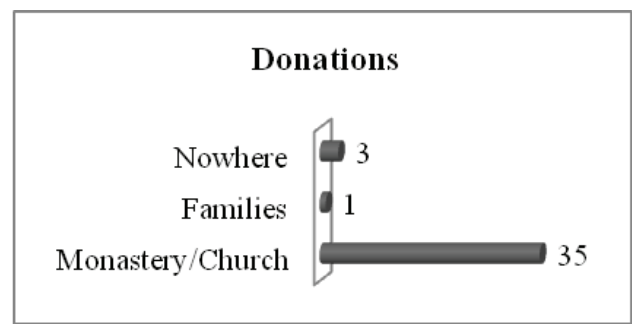

Source: Authors 
Based on these answers we can observe that the absolute majority of passengers made a donation, and in that way confirmed the economic contribution to the local community in Kosovo and Metohija.

The following chart will show the respondents' answers to the question: "Did you spend your money in a place which the trip organizer did not announce as a possible shopping destination?"

Picture 4: The structure of answers to the question "Did you spend your money in a place which the trip organizer did not announce as a possible shopping destination?"

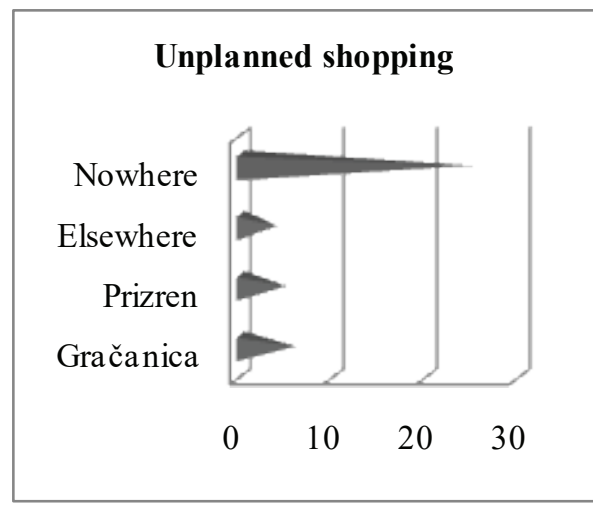

Source: Authors

Based on these answers we can observe that the absolute majority of passengers spent their money in places which were announced in advance as a possible shopping destination. We can conclude that the economic contribution which was directed at the local community of Kosovo and Metohija has kept its direction. When asked "Did you like your stay in Kosovo and Metohija?" most of the respondents (34 of them) were thrilled, four of them were quite satisfied, while no passengers had a negative comment.When asked "Will your current stay affect whether or not you will visit Kosovo and Metohija again, provided you have the possibility?" all respondents answered positively.

Most of the respondents plan to revisit Kosovo and Metohija, based on which we can conclude that religious and cultural tourism promote the local community as a tourist destination.Since all respondents answered that they will recommend their relatives, friends and neighbors to visit Kosovo and Metohija after they return, we can again conclude that religious and cultural tourism promote the local community as a tourist destination.When asked "During your stay in Kosovo and Metohija, was your safety endangered and did you have any kind of unpleasant experience?" all respondents answered that there were no unpleasant situations.

\section{Conclusion}

The study results show that the respondents' cause for the visit to Kosovo and Metohija was primarily religious, and then cultural tourism. Also, the visitors spent 
their money in shops, monasteries, churches and made donations, which contributed to economic growth of this region.

The visitors were amazed by cultural and religious tourism and the cultural heritage of Kosovo and Metohija during this two-day trip, and they have expressed their wishes to revisit this destination in the future, as well as to recommend it to all their acquaintances. Most of the participants in this trip found out about it by their relatives' or friends' recommendation, and for that reason we should research ways to expand recommendations to social networks and other advertising channels, in order to achieve more successful marketing. The visitors did not have unpleasant experiences while touring the significant sacred locations this time, which is encouraging for future trips and visits. Based on the answers to the questions asked, we can conclude that cultural and religious tourism represent the real sanctity for our people and that they bring significant contribution to regional and cultural development of this area.

From all the above in the paper, the studied professional literature and the obtained research data, it can be concluded that the general hypothesis X0: Religious and cultural tourism is of great importance for the development of the local community in Kosovo and Metohija, fully confirmed. Also, special hypothesis X1: A large number of monasteries and churches located in this area, represents true holiness for our people, was confirmed by insight into the obtained research data.Certainly, when drawing conclusions, we must be careful if we keep in mind that the research sample is small. In that sense, opportunities open up for further research and expansion of what has been done.

\section{References}

Anđelković, B. (2019). Uloga verskog turizma u stvaranju „hijerarhije“manastira kod poklonika Srpske pravoslavne crkve1. Glasnik Etnografskog instituta SANU LXVII(2), 421-443.

Avramović, Z. (2018). Borba za Kosovo i Metohiju u novim okolnostima. In. D. Stanić (Ed.), Kosovo i Metohija: juče, danas, sutra, Zbornik, 2018 (p.30), Novi Sad: Matica srpska.

Bogan, E., Cercleux, A. L., \& Constantin, D. M. O. (2019). The role of religious and pilgrimage tourism in developing and promoting the urban tourism in Buchares. Quality-Access to Success, 20.

Chianeh, R., Del Chiappa, G., \& Ghasemi, V. (2018). Cultural and religious tourism development in Iran: prospects and challenges. Anatolia, 29(2), 204-214.

Damnjanović, A. M., Dašić, D. R., \& Đurašković, J. A. (2016).Kulturni resursi kao ekonomski potencijal nacionalnih ekonomija, In: Vladušić, Lj, (Ed.) Tourism and competitiveness, JBF2016, Jahorina: Ekonomski fakultet Pale, Republika Srpska Bosna i Hercegovina.

Đukić Dojčinović, V. (2005).Kulturni turizam, Klio, Beograd.

Durán-Sánchez, A., Álvarez-García, J., Río-Rama, D., De la Cruz, M., \& Oliveira, C. (2018). Religious tourism and pilgrimage: Bibliometric overview. Religions, 9(9), 249. 
Eidelman, B. M., Fakhrutdinova, L. R., Bunakov, O. A., Gabdrakhmanov, N. K., \& Grigorieva, E. V. (2017). Religious tourism in the tourism system. Revista San Gregorio, (20), 96-103.

Heidari, A., Yazdani, H. R., Saghafi, F., \& Jalilvand, M. R. (2017). Developing strategic relationships for religious tourism businesses: a systematic literature review. EuroMed Journal of Management, 2(1), 77-98.

Katanić, Z. (2017). Valorizacija kulturnih vrednosti Kosova i Metohije u funkciji turističke ponude (Doctoral dissertation, Univerzitet Singidunum, Studije pri univerzitetu).

Kilipiris, F. E., Dermetzopoulos, A. (2016). Streets of Orthodoxy: Developing religious tourism in the Mount Paiko area, Central Macedonia, Greece. International Journal of Religious Tourism and Pilgrimage, 4(7), 31-38.

Mićunović, G., Novaković, N.,\& Stefanović, G. (2015). Verski turizam i mogući negativni efekti u odnosu na manastire, Bizinfo, 6(1), 43-52.

Mihajlović, P.,\& Mihajlović,Lj. (2013). Institucionalna zaštita kulturnog nasleđa na Kosovu i Metohiji. In. U. Šuvaković (Ed.), Kulturno nasleđe na Kosovu i Metohiji, Istorijske tekovine Srbije na Kosovu i Metohiji i izazovi budućnosti, Zbornik 2, 2013 (pp. 667681). Kosovska Mitrovica: Filozofski fakultet u Prištini, Univerzitet u Prištini.

Milosavljević, S. (2013). Demografsko- ekonomskaanalizastanjausrpskimenklavama ufunkcijiunapređivanjastrateškograzmišljanja i delovanja na Kosovu i Metohiji. In. U. Šuvaković (Ed.), Kulturno nasleđena Kosovu i Metohiji, Istorijske tekovine Srbije na Kosovu i Metohiji i izazovi budućnosti, Zbornik 2, 2013 (pp. 885-895). Kosovska Mitrovica: Filozofski fakultet u Prištini, Univerzitet u Prištini

Molnar, D., \& Manić, E. (2018). New subregionalization for new regional policy of Serbia. Anali Ekonomskog fakulteta u Subotici, (40), 3-19.

Nedeljković, M. D. (2018). Multikonfesionalnost lokalne zajednice kao komparativna prednost za razvoj (verskog) turizma - primer Novog Sada. Religija i Tolerancija, 16(30), 299-321.

Petroman, I. (2013). Types of cultural tourism. Scientific Papers Animal Science and Biotechnologies, 46(1), 385-388.

Pourtaheri, M., Rahmani, K., \& Ahmadi, H. (2012). Impacts of religious and pilgrimage tourism in rural areas: The case of Iran. Journal of Geography and Geology, 4(3), 122-129.

Radović, V., Katanić, Z., \& Pezo, L. (2018). Importance of the valorisation of Serbian cultural and historical heritage of Kosovo and Metohija in the tourism development process. TIMS. Acta, 12(1), 5-15.

Richards, G. (2005), The scope and significance of cultural tourism, CAB International, Wallingford.

Sagić, Z., Lakićević, M., \& Durkalić, D. (2019). Analysis of turnover in a rural tourism destination - Case study of Ivanjica, Economics of Agriculture, 66(3), 835-850.

Sančanin, B., Perić, G., \& Stojiljković, M. (2019). Cultural-historical resources as initiators of tourism development in Sremski Karlovci. Hotel and Tourism Management, 7(2), 77-85. 
Sivakumar, V., Saranya, P. R., Iyappan, A., \& Leelapriyadharsini, S. (2019). A preliminary review of the cultural heritage and emerging pilgrimage tourism in Tamil Nadu, Journal of Tourism, Hospitality \& Culinary Arts. 11(2), 94-105.

Skoultsos, S., \&Vagionis, N. (2015). Cultural and ReligiousTourism as parts of Greek Tourism product. In IMIC 1st Internationa lConference on Experiential Tourism, Santorini, Greece.

Šušić, V., \& Đorđević, D. Ž. (2019). Modern tendencies of international tourism development. Ekonomika, 65(2), 27-37.

Yakunin, V. N., Yamashev, V. M., Anuchin, O. I., Adaevskaya, T. I., \& Ovsyannikova, N. V. (2016). Religious tourism and pilgrimage in Russia: cultural-historical analysis. The Turkish Online Journal of Design Art and Communication, 6(NVSPCL), 25952603.

Živadinović, B., \& Knežević, M. (2018). Srpski srednjovekovni manastiri kao spona između verskog i kulturnog turizma. Culture, heritage and tourism development, 200-206.

World Tourist Organization (UNWTO): www2.unwto.org (Accessed on 29 September 2020). 